\title{
THE ROLE OF SOCIAL STUDIES AND HISTORY LEARNING IN JUNIOR HIGH SCHOOL IN STRENGTHENING THE STUDENTS CHARACTER
}

\author{
Leo Agung S. \\ Historical Education Study Program of FKIP, Sebelas Maret University, Surakarta \\ leo.agung56@yahoo.co.id
}

\begin{abstract}
Nowadays, in Indonesia a variety of violence and moral degradation event still occur. The moral degradation phenomenon (among others) is indicated with the spread of violence, criminality, drug abuse, free sexual-intercourse and other misbehaviors. Multidimensional crisis and nation deterioration originates essentially in selfesteem, and failure in developing nation's character education. Essentially, Social Science learning aimed to develop personal, social, and intellectual behavior. Thus, Social Science learning in Junior High Schools becomes a means and opportunity of strengthening the student characters such as sense of critical, discipline, environment awareness, social care, religious, having reading interest, loving to homeland, willing to sacrifice, creative, honest, independent, and hard work, in order to build the nation and the state better, more prosperous, secure, and peaceful.
\end{abstract}

Keywords: Social Science learning, character education, personal competency, social and intellectual.

\begin{abstract}
ABSTRAK
Dewasa ini, di Indonesia terjadi beragam kekerasan dan degradasi moral yang masih terus terjadi. Fenomena degradasi moral diindikaisikan dengan beragam kekerasan, kriminalitas, penggunaan narkotika, pergaulan bebas, dan berbagai penyimpangan perilaku. Krisis multidimensional dan berbagai kerusakan tersebut pada dasarnya berasal dari harga diri, serta kegagalan dalam pengembangan pendidikan karakter bangsa. Di satu sisi secara esensial Pendidikan IPS bertujuan untuk membangun kemampuan personal, sosial, dan intelektual. Dengan demikian pembelajaran IPS di SMP menjadi sarana dan kesempatan untuk memperkuat karakter siswa, seperti sikap kritis, disiplin, peduli lingkungan, peduli sosial, agama, memiliki minat baca, cinta ke tanah air, rela berkorban, kreatif, jujur, independen, dan kerja keras, dalam rangka membangun bangsa dan negara yang lebih baik, lebih sejahtera, lebih aman, dan damai.
\end{abstract}

Kata kunci: pembelajaran Ilmu Sosial, pendidikan karakter, kompetensi personal, sosial dan intelektual.

\section{INTRODUCTION}

Education is a very fundamental aspect of life for nation and state development. As mentioned in Law No. 20 of 2003 about National Education system (2007: 8), national education functions to develop competency and to provide disposition, also civilizing nation prestigious in the attempt of intellectualizing the nation life. It aims to develop the students' potency in order to be faithful and devout human beings who have noble character, knowledge, competen- cy, creativity, independency, democracy and responsibility

The formulation of national education is very ideal; but according to historical experience, the implementation of education organization as the nation building process is still worrying. Rokhman, Nurhadi, and Muhsinatun (2006: 116) stated that the development of society life is still characterized with various moral gaps, noble character, social problem, economy, politics, and nation selfesteem. These indicate that our education has not been able to develop Indo- 
The Role of Social Studies ... - Leo Agung S.

nesian people and society as expected.

The recent problem of moral degradation befalls some young generation. These indicate by the spread of violence, criminality, drug abuse, free sex, and other various misbehavior cases (Lubis, 2009: v). On the other hand, many young generations fail to appear noble character as the parents' expectation. Decorum, friendliness, tolerance, humbleness, helpfulness, social solidarity and etc are inherent less strongly to themselves (Supriyoko, 2003: 3). All of those show that Indonesian education is inclined to knowledge dimension and ignores noble character education (Suyanto, 2000: 153).

The recent problem of moral degradation is inconsistent with the meaning and purpose of social science learning. For social science education and learning, in addition to be academic in nature, also implant values, develop social problem solving skill, reconstruct event, wisdom problem and moral tenet, independency, responsibility, discipline, and entrepreneur spirit (Rokhman, Nurhadi, and Muhsinatun, 2006: 117). Cholisin and Hisyam (2006: 131-132) stated that the fundamental substantive objective of Social Studies teaching at school is to improve behavior, attitude, skill, and knowledge (abbreviated into BASK) of students.

The reality in learning process at school including Social Science learning in Junior High Schools based on KTSP (Education Unit Level Curriculum) or 2013 Curriculum, in either learning process or evaluation, the school or the teacher emphasizes more on cognitive aspect than on affective or psychomotor ones. Meanwhile, based on a research in Harvard University of United States (Ibrahim, 2000), in fact, an individual's success is determined not only by technical knowledge and ability of hard skill, but also by the ability of managing him/herself and others (soft skill). This study reveals that success is determined by only 20 percent of hard skill and the rest of 80 percent is determined by soft skill. Even the most success people in the world can success because of more support from soft skill rather than hard skill ability. It presupposes that character education is very important to students (Amril, 2006: Koesoema, 2010).

Social Science learning plays an important role in establishing the nation character. For social learning has similarity to value education or character education, each of which aims to make the students the good citizens who care about their social and environment problems, and have high nationality feeling. For that reason, it is time and it is very important to implement character education in Social Science learning.

\section{SOCIAL SCIENCES LEARNING}

In KTSP of 2006 or Curriculum of 2013 documents, Social Science is one name of subject provided at elementary and secondary school levels. Social Science subject is a name of integrated subject composed of history, geography, and economy, as well as other social science subjects (Sapriya, 2007: 7). The name of Social Science is parallel with the name of Natural Science (Science), as the integration of biology, chemistry, and physics subject.

Social Science is an education program selecting education material from social sciences and humanity (education and history) disciplines organized and presented scientifically and psychologically for education purpose based on Pancasila (Five Principles) and Indonesian culture (Soemantri, 2001: 92). Social Science is an integration of various social and humanity disciplines such as: sociology, history, geography, economy, 
and culture. Social Science is formulated based on reality and social phenomenon manifesting an interdisciplinary approach of social science aspects and branches. For that reasons, Social Science can be said as a study on the combination between sciences in Social Science clump and also humanity to bring out social performers that can participate in solving socio-nationality problems. The material of study pertains to event, a set of facts, concept, and generalization related to actual issues, social phenomenon and reality as well as local potency. Furthermore in Law No.20 of 2003 about National Education System, Social Science is explained as the material of study compulsorily contained in the curriculum of primary and secondary education, among others, encompassing geography, history, economy, and sociology, aimed at developing knowledge, understanding, and analysis ability of students over the society's social condition.

Social sciences, as an education program, not only provide knowledge concept, but it should be build the students knowledge of their rights and obligations as citizens or members of society, then they will have responsibility for common welfare. The objective of Social Science subject is to prepare the students to be good citizens based on Pancasila (Five Principles) and UUD 1945 (1945 Constitution) emphasizing on developing individuals who can understand the problems existing in environment, coming either from social environment discussing inter-human interaction or from natural environment discussing interaction between human beings and their environment, as both an individual and a member of society. In addition, they should be able to think critically and creatively, and to continue and to develop the nation's cultural values. Social Science subject aims to develop the stu- dents' potency in order to be sensitive to social problems occurring within the society, to have positive mental attitude to correcting any gaps occurring, and to deal with skillfully the daily problems occurring, befalling themselves or society (Sumaatdmadja, 1984: 20).

In addition, Fraenkel (1980: 8-11) divided the objective of Social Science into four categories: knowledge, skill, attitude, and value. Knowledge is skill and understanding on some information and ideas. The objective of knowledge is to help the students learn more about themselves, their physique, and social world. For example, the students are introduced with the concepts of natural environment, artificial environment, family, neighbor, and etc. Skill is the development of certain abilities so that the knowledge acquired is used. Several skills existing in Social Science is: (1) Thinking skill is the ability of describing, defining, classifying, formulating hypothesis, generalizing, predicting, comparing, and contrasting, and bringing about new ideas; (2) Academic skill is the ability of reading, studying, writing, speaking, listening, reading and interpreting map, outlining, making chart and note; (3) Research skill is to define problem, formulate hypothesis, find and collect data relevant to problem, analyze data, evaluate hypothesis and draw a conclusion, support, reject or modify hypothesis appropriately, and (4) Social Skill is the ability of cooperating, contributing to group duty and discussion, understanding nonverbal signs delivered by others, responding to by means of helping other problems, confirming others' strength, and demonstrating appropriate leadership. Attitude is the fluency of developing and accepting beliefs, interests, perspectives, and certain predisposition. Meanwhile, value is the fluency of holding on a number of commitments in-depth, supporting when 
The Role of Social Studies ... - Leo Agung S.

something is considered as important with appropriate measure (action).

Specifically, Sapriya (2009: 201) explained that the objectives of Social Science subject in Junior High Schools (SMP/MTs) are as follows: 1) to identify the concepts related to society life and its environment, 2) to have basic competency to think logically and critically, curiosity, inquiry, problem solving, and skill in social life, 3) to have commitment and awareness on social values and humanity, 4) to have abilities of communicating, cooperating, and competing within plural society at local, national and global.

From various formulations above, generally the competency and the objectives of Social Science learning are to deliver, to guide, and to develop the potency of students in order (1) to be good citizens and world members; (2) to develop critical thinking ability wisely to understand, to treat and to participate in solving social problem; and (3) to build commitment to humanity values and to appreciate as well as to develop noble values and Indonesian culture.

\section{CHARACTER EDUCATION}

Literally, character is defined as "mental or moral quality; moral strength, name or reputation" (Hidayatullah, 2010: 9). Character is the way of thinking and behaving becoming the typical characteristics of an individual to live and cooperate, in family, society, nation or state environment. An individual with good character is the one who can make decision and is ready to responsible for the consequence of decision he/she makes (Suyanto, 2010).

So far, there are three focuses of dominant character education. Firstly, character education concentrates on learning (teaching values). Secondly, character education concentrates on val- ue clarification, and thirdly, character education uses Kohlberg (character development) moral growth approach. Character education concentrating on learning emphasizing on certain values that should be studied, such as honesty, critique, care about, tolerance, and etc, in order to be find out and understood by students. Value clarification emphasizes on moral reasoning process and value selection the students should have, while the focus on moral character growth emphasizes on behavior reflecting on value acceptance and on motivation element, as well as relatively stable personality aspect that will guide individual action. The first focus emphasizes on knowledge and understanding (intellectual); the second emphasizes on conduct, and the third on internal motivation growth in establishing values in line with the individual moral development stages.

Character education is a system of implanting character values to the members of school including knowledge, awareness or willingness, and action to implement such the values, either to God, self, fellow human being, environment, or nationality, in order to be a perfect human being. In character education at school, all the stakeholders should be involved, including the components of education themselves: curriculum, learning and assessment process, relationship quality, subject handling and management, school management, implementation of activity or cocurricular activity, infrastructure, funding, and work ethos of all of school members and environment (Akhmad Sudrajat, 2010).

Character education is stunning noble character education, involving cognitive, feeling, and action aspects. Lickona (2000) stated that without these three aspects, character education will be ineffective. It is in line with Golemen 
(2000) stating that character education is essentially the value education involving cognitive, feeling and action aspects.

Through character education applied systematically and sustainably, an individual will be smart emotionally. This emotional quotient (intelligence) is the important supply in preparing the children for future, because an individual will deal with any type of life challenge more easily and successfully, including the challenge to be successful academically. There are nine character pillars coming from universal noble values: firstly, the character of loving to God and all of its creatures; secondly, independency and responsibility; thirdly, honesty/trusteeship, diplomacy; fourthly, respect and decorum; fifthly charity, helpfulness, and mutual cooperation; sixthly, self-confidence and hard work; seventhly, leadership and justice; eighthly, good and humbleness, and; ninth, tolerance character, peace, and unity (Suyanto, 2011).

Those ninth character pillars are taught systematically in holistic education model using knowing the good, feeling the good, and acting the good methods. Knowing the good can be taught easily because knowledge is only cognitive in nature. After knowing the good, feeling loving the good should be growth, namely, how feeling and loving the virtue can be an engine that can make an individual is willing to do some good. Furthermore, awareness grows that an individual want to virtuous behavior because of his/her loving to such the virtue. Having been accustomed with the virtue, acting the good would change into a habit.

Considering grand design developed by National Education Ministry (2010), psychologically and socialculturally, the character establishment inside individual constitutes the function of individual human potencies (cognitive, affective, conative, and psychomotor) in social-cultural interaction context (in family, school, and society) and lasts long life. The character configuration in the context of psychological and socio-cultural process totality can be grouped into: Spiritual and emotional development, intellectual development, physical and kinesthetic development, and affective and creativity development diagrammatically can be illustrated below.

\begin{tabular}{|c|c|}
\hline $\begin{array}{c}\text { Intellectual } \\
\text { development } \\
\text { Smart }\end{array}$ & $\begin{array}{c}\text { Spiritual \& emotional } \\
\text { development } \\
\text { Honest, responsible }\end{array}$ \\
\hline $\begin{array}{c}\text { Sport \& kinesthetic } \\
\text { Clean, Healthy, } \\
\text { interesting }\end{array}$ & $\begin{array}{c}\text { Affective \& Creative } \\
\text { development } \\
\text { Care about and } \\
\text { creative }\end{array}$ \\
\hline
\end{tabular}

\section{CHARACTER REINFORCEMENT}

In line with reformation movement, education should reformulate its philosophical orientation. By the new orientation, education teaches not only cognitive (knowledge) domain problems, by ignoring moral and social action aspect. Because it is moral and social action that should get attention at higher scale for an education to be able to create the students into good and responsibility citizens as the ultimate goal that should be achieved in education process (Suyanto, 2006: 140).

Through such of these approaches, we can implant moral and social action skills to the students to deal with actuality morality problems such as tolerance, different opinion, empathy, pluralism, honesty, legal awareness, social orderliness, human right, democratization of various life aspects, local wisdom, and etc. Local wisdom should get attention to be developed in education to enable us designing education program with partiality, standing, and thus go down 
to earth on to glorious tradition and societal rule and order in local area. Thus, we evade the apprehension about the loss of self-esteem as citizen due to the drifter globalization stream.

The students of Junior High Schools are young generation and nation asset that should be prepared for having disposition and character as mentioned above. These students of Junior High Schools generally are in sensitive development age to find their selfidentity or in establishing their personal disposition and character. In addition education within family and society, formal education at school is a very strategic way of creating young generation into Indonesian human who has intact disposition and character (Soemantri, 2001: 104).

It is well established that education in faith and piety field will create Indonesian human who has personality and noble character. Nevertheless, it is noteworthy that education in faith and piety field alone is not enough to establish disposition and character. The establishment of disposition and character should be carried out in integrative manner in all subjects including Social Science, because Social Science contributes significantly to the attempt of creating the nation disposition and character.

Sumaatmadja (2005) stated that value education is the attempt of manifesting the intact human, the one faithful and pious to the Almighty God, having noble character, humane attitude, and caring about others' need and interest, essentially becoming an educated human being in the term of faith, knowledge and character, and being the good state and world citizens. Furthermore, Sumaatmadja (2005) suggested that the values that can be developed in Social Science include: educative, practical, theoretical, philosophical, and divinity values. Educative values including feeling, awareness, comprehension, attitude, care about, and social responsibility of students improve through Social Science education. The awarness and social responsibility is developed concretely to change the students' behavior such as cooperating and helping the needy. Practical value should, of course, be adjusted with age level and daily activity of students. The practical knowledge of Social Science is beneficial in attending news, listening to radio, reading magazine, and dealing with daily life problems. In the term of theoretical value, the students are built and developed for their reasoning ability toward the sense of reality, sense of discovery, and sense of inquiry. Regarding philosophical value, the students are developed for their awareness of and comprehension of their existence amid the society, even amid the universe. From such the awareness, they are made aware of their own contribution to the society, even to environment entirely. Divinity value becomes our foundation to approach ourselves, to improve our faith, and piety to God. Our admiration as human beings to all of His creatures, either physical-natural or life phenomenon.

In National Education Ministry (2010: 11-22), it is mentioned that cultural and character education should be implied in Social Science Learning, so it should be integrated into syllabus and RPP (Learning Plan Implementation. It means that Social Science as one of subjects at school has same duty and responsibility as other subjects for developing it. Cultural values and nation characters developed through Social Science, among others, include: religiosity, nationality spirit, loving to homeland, willing to sacrifice, appreciating achievement, loving to reading, critical, disciplined, social awareness, independent, creative, honest, and hard work. 
Recalling that the objective of Social Subject is to develop the students' potency in order to be sensitive to social problems occurring within the society, to have positive mental attitude to correcting any discrepancies occurring and to deal with the daily problems skillfully, befalling either themselves or society life (Depdiknas, 2006: 1).

The education proceeding at school is a purposeful process; the objective of education is essentially to humanize young man (Driyarkara, 1986: 3). This objective directs education to create the human being who not only can master knowledge and technology or has high intellectuality, but also can master and implement the values into living within nation and state. Just like Goleman (2001) stated that intelligence quotient alone is not enough, it should be accompanied with emotional quotient and spiritual quotient. Character value learning does not stop at cognitive level, but should come up internalization and real experience in the students' life in living within family and society. It is consistent with what Ki Hajar Dewantara has taught, "Tringa Concept" including ngerti (knowing), ngrasa (understanding), and nglakoni (doing) (Wangid, 2009: 130; Rahardjo, 2010: 63), reminiscent of tenet, ideology we hold on requiring understanding, awareness and sincerity in implementation. Knowing and understanding are not enough without feeling, realizing, and then struggling for and implementing; it is stated that knowledge without charity is like wood tree that will not produce any fruit (Wardana, 2014: 135).

Still related to the implantation of values into Social Science learning, the result of Supardi and Saliman (2011)'s study shows that the teachers of Social Science implant the values through learning material and learning activity such as implanting the values of loving to homeland, willing to sacrifice, persistence, honesty, creativity, hard work, criticality, and discipline. To achieve those objectives, Social Science learning is conducted through Cooperative Learning, because it can touch personal, social and intellectual abilities of students. It is supported by Attle and Baker (2007) and Ahmed (2009) concluding that through cooperative learning, (a) the students will participate actively, (b) the interpersonal relationship between heterogeneous students improves, and (c) the students' learning achievement improves.

In addition, to establish the role of Social Science learning in creating the nation character, according to Sardiman (2010: 158), the following supporting factors are required: (a) role model, (b) active-participative, creative-innovative learning models with various accustoming programs, (c) conductive-educative education environment preparation, for example, posting various slogans that can motivate and give spirit in living and life with more character, (d) cooperation between schools and parents and surrounding society, and (e) political will of government.

Thus, Social Science learning plays an important part in strengthening the character of multicultural students. It is confirmed by Musadad and Wasino (2012: 226) about "Multicultural Education-Based Historical-Social Science Training Model for Junior High School Teachers" stating that Social Science subject is administered to build the young generation's character as a democratic and responsible citizen. Furthermore, Hasan's (2012: 81) study entitled "Historical Education to Strengthen Character Education" confirmed that Historical-Social Science learning is administered at school as the attempt of building nation and character. It has been confirmed by President Susilo 
The Role of Social Studies ... - Leo Agung S.

Bambang Yudhoyono as well that the target of education is not only intellectuality but also moral and noble character, disposition, value and tough, superior and lofty personality (Yudhoyono, 2011).

\section{CONCLUSION}

Character education focusing on the creation of students' self-identity into those smart and having good character should be attempted through informal, formal and non-formal education. Formal education includes school, particularly through Social Science learning, because the objective of Social Science not only pertains to cognitive aspect (intellectuality) but also should touch the affective (personal ability) and psychomotor aspects or social ability. In other words, it Social Science learning is essentially the implantation of attitude, values and moral. For that reason, Social Science teacher should be able to package and then to implement it into learning. In this case, the equally important for the success of value implantation is the teacher's role model. Thus, Social Science will be able to strengthen the character of students.

\section{ACKNOWLEDGMENT}

This writing is a part of College Superior Research (PUPT) funded by BOPTN from High Education of 2015, entitled: "The Development of Local Wisdom-Based Social Science Learning Model with Bengawan Solo as Learning Source in the Attempt of Improving Learning Quality and Strengthening the Character of Students in Surakarta City". For that reason, here the author would like to thank to Directorate General of High Education for chance and fund it has given for this research. He also would like to thank to Prof. Sulistyo Saputro, M.Si., Ph.D. the Chairman of LPPM UNS Surakarta along with all of his staffs for their management or coordination of the research and service to public. He would like to thank to Prof. Dr. Wasino, M.Hum as the Chief Editor and Staff of PARAMITA journal for publishing his writing. Finally, the author would like to thank to Prof. Dr. Hermanu Joebagio, M.Pd. for his recommendation and input. May the Almighty God always give His bless to all of those helping the author in this writing.

\section{REFERENCES}

Ahmed, Fareed. 2009. "Effect of Cooperative Learning on Students' Achievement at Elementary Level". Article. The Internationa 1 Journa 1 of Learning.Vol.17.No.3, pp.127-142. Downloaded on January 3, 2013.

Amril, M. 2006. "Implementasi Klarifikasi Nilai Dalam Pembelajaran dan Fungsionalisasi Etika Islam". Al Fikra :Islamic Scientific Journal, Vol.5 No.1 January-June 2006. pp.58-93 downloaded on May 5, 2013.

Attle, Simon dan Baker, Bob. 2007. "Cooperative learning in a comparative environment : classroom applications". International Journal and Learning in Higher Education. Volume 19. No1, pp.77-83. Downloaded on January 3, 2013.

Depdiknas. 2006. Model Pembelajaran IPS Terpadu SMP/MTs/SMPLB. Jakarta: Badan Penelitian dan Pengembangan Pendidikan Nasional Pusat.

Goleman, Daniel. 2001. Kecerdasan Emosional translation by Hermaya T. Jakarta: Gramedia Pustaka Utama.

Hasan, Hamid. 2012. "Pendidikan Sejarah untuk Memperkuat Pendidikan Karakter." Paramita. Journal of History and Historical Learning.Vol.22 No.1 - January 2012. 
pp.81-95. Downloade on April 5, 2014

Ibrahim, M, et al.2000. Pembelajaran Kooperatif. Surabaya : Universitas Negeri Su rabaya Press.

Kemendiknas. 2010. Pembinaan Pendidikan Karakter di Sekolah Menengah Pertama. Jakarta : Kemendiknas

Koesoema, Doni A. 2010. Pendidikan Karakter Strategi Mendidik Anak di Zaman

Global. Revision Edition. Jakarta : PT Gramedia Widiasuara Indonesia.

Likcona, Thomas. 2000. "Talk About Character Education" interview by Early Chilhood Today, ProQuest Education Journal, April 2010 downloaded, on May 10, 2011.

Lickona, Thomas. 2012. Education for Character: How Our School can Teach Respect and Responsibility. Translation by Juma Abdu Wamaungo. Jakarta

Lubis, Mawardi. 2009. Evaluasi Pendidikan Nilai. Second edition. Yogyakarta : Pustaka Pelajar.

Musadad, Ahmad Arif dan Wasino. 2012. "Model Pelatihan IPS-Sejarah Berbasis Pendidikan Multikultural untuk Guru SMP". Paramita. Vol..22 No.2 2012.p. .226-227. Downloade on January 3, 2015

Nur Rokhman.M, Nurhadi, dan Muhsinatun S. 2006. "Pengembangan Kurikulum Pengetahuan Sosial Terpadu secara Tematik di Tingkat SLTP : Sebuah Pemikiran Awal". ISTORIA. Journal of Education and Historical Science. Vol.1 No.2, March 2006. Yogyakarta :
FISE.

Sardiman, A.M. 2010. “Revitalisasi Peran Pembelajaran IPS Dalam Pembentukan Karakter Bangsa. Cakrawala Pendidikan. May 2010. Year XXIX, pp.147-160. Special Edition of UNY Anniversary. Downloaded on December 12, 2011.

Yudhoyono, Susilo Bambang. 2011. Pendidikan Karakter Sangat Penting. Available in http://nasional.kompas. com.read/2011/05/20/21473385/ SBY. Pendidikan.Karakter. Sangat. Penting. Downloaded on May 10, 2013.

Sapriya.2009. Pendidikan IPS Konsep dan Pembelajaran. Bandung : PT Remaja Rosdakarya.

Supriyoko, Ki. 2003. “Menuju Masyarakat Tertib Damai Salam Bahagia Sebagai Karakter Bangsa Masa Depan", Article. Presented in Cultural Gathering Forum . Yogyakarta : May 19-20, 2003.

Suyanto. 2006. Dinamika Pendidikan Nasional Dalam Percaturan Global Dunia. Jakarta: PSAP Muhammadiyah.

Suyanto, Urgensi Pendidikan Karakter, a v a l a ble i n h t t p:/ www.mandikdasmen.depdiknas.go.i $\mathrm{d} /$ web/pages/urgensi.html, downloaded on February 1, 2011

Wangid, Muhammad Nur. 2009. Sistem Among Pada Masa Kini : Kajian Konsep dan Praktik Pendidikan. Jurnal Pendidikan. Vol.39. No.2, November 2009, pp.129-140. Downloaded on January 7, 2013. 